Published in final edited form as:

Curr Opin Pulm Med. 2017 November ; 23(6): 522-529. doi:10.1097/MCP.0000000000000426.

\title{
Autoimmunity in narcolepsy
}

\author{
Melodie Bonvalet ${ }^{1}$, Hanna M. Ollila ${ }^{1,2,3}$, Aditya Ambati ${ }^{1}$, and Emmanuel Mignot ${ }^{1}$ \\ ${ }^{1}$ Stanford University School of Medicine, Department of Psychiatry and Behavioral Sciences, \\ Center for Sleep Sciences, Palo Alto, CA 94304, USA ${ }^{2}$ National Institute for Health and Welfare, \\ Public Genomics Unit, Helsinki, Finland ${ }^{3}$ Institute for Molecular Medicine FIMM, University of \\ Helsinki, Helsinki, Finland
}

\begin{abstract}
Purpose-Summarize the recent findings in narcolepsy focusing on the environmental and genetic risk factors in disease development.

Recent findings-Both genetic and epidemiological evidence point towards an autoimmune mechanism in the destruction of orexin/hypocretin neurons. Recent studies suggest both humoral and cellular immune responses in the disease development.
\end{abstract}

Summary-Narcolepsy is a severe sleep disorder, where neurons producing orexin/hypocretin in the hypothalamus are destroyed. The core symptoms of narcolepsy are debilitating, extreme sleepiness, cataplexy and abnormalities in the structure of sleep. Both genetic and epidemiological evidence point towards an autoimmune mechanism in the destruction of orexin/hypocretin neurons. Importantly, the highest environmental risk is seen with influenza-A (pH1N1) infection and immunization. However, how the cells are destroyed is currently unknown. In this review we summarize the disease symptoms, and focus on the immunological findings in narcolepsy. We also discuss the environmental and genetic risk factors as well as propose a model for disease development.

\section{Keywords}

Sleep disorders; autoimmune disease; genetics; infectious diseases

\section{Introduction}

Type 1 narcolepsy is a chronic neurological disorder defined by the presence of excessive daytime sleepiness and cataplexy, episodes of muscle weakness triggered by strong emotions. In almost all type 1 narcolepsy patients, the disease is caused by lack of hypocretin (orexin) neurotransmitter [1]. Hypocretin is a wake promoting neurotransmitter, produced by neurons in the lateral hypothalamus [2,3]. A characteristic selective loss

Correspondence to Melodie Bonvalet and Emmanuel Mignot, Stanford University Center for Sleep Sciences, 3165 Porter Drive, Palo Alto, CA 94304, USA; Phone: 1 (650) 725-6517, FAX: 1 (650) 725-4913, mignot@ stanford.edu, bonvaletmelodie@gmail.com.

Conflicts of interest

Authors declare no conflict of interests 
(>90\%) of hypocretin producing neurons is seen in narcoleptic patients [4, 5]. In addition, both hypocretin knockout mice as well as dogs with mutations in the hypocretin receptors manifest cataplexy and narcolepsy. In humans, in the majority of cases, the loss of hypocretin is somewhat gradual and occurs postnatal [6]. Furthermore, there is convincing genetic and epidemiological evidence suggesting an autoimmune mediated hypocretin neuronal loss.

The first clue for an autoimmune disease etiology in narcolepsy was observed in 1980s when a strong association with HLA-DR2 haplotype was discovered [7]. Fine mapping of the HLA-DR2 revealed an association with HLA-DQB1*06:02. In narcolepsy cases, 87-98\% of patients are $\mathrm{DQB} 1 * 06: 02$ positive, depending on population and inclusion criteria [8]. These findings were later complemented by genome-wide association studies (GWAS), which showed that narcolepsy associated with variants within genes that regulated immune system [9-11]. These findings further support an autoimmune basis as the cause of hypocretin cell destruction.

In 2009-2010 a striking increase in narcolepsy cases was seen in Northern Europe, especially in children. This increase was quickly traced back to a widespread vaccination campaign against pandemic H1N1 Influenza A (pH1N1) that used a vaccine brand called Pandemrix ${ }^{\circledR}$ [12]. Similarly, in China increased narcolepsy onsets were seen with natural pH1N1 infections [13]. H1N1 Influenza and the associated Pandemrix ${ }^{\circledR}$ vaccination is likely to be the specific environmental triggers for narcolepsy onset. Taken together, the strong HLA association, the specific loss of hypocretin neurons and the H1N1 Influenza exposure as an environmental trigger suggests an autoimmune basis for narcolepsy. However, the mechanisms by which hypocretin neurons are destroyed are yet to be elucidated. This review aimed at addressing the epidemiology, genetics and the immunological aspects of narcolepsy that support an autoimmune basis.

\section{Epidemiology of narcolepsy - role of influenza vaccination and infection}

Based on several population studies, type 1 narcolepsy has a worldwide average prevalence of $0.03 \%$ [14-20]. It is however unequally distributed across populations with up to $0.16 \%$ in Japan [21] and low prevalence in Jewish and Arabic populations [22, 23]. According to HLA population studies, the frequency of $H L A-D Q B 1 * 06: 02$ genotype cannot by itself explain this disparate distribution $[8,22,24-28]$.

In 2009, a swine-origin H1N1 influenza A emerged [29]. In a couple of months, the virus reached 30 countries around the world. In response, a global vaccination campaign was launched towards the new pH1N1 emerging threat. Vaccines used during the vaccine campaign are summarized in vaccine coverage in Figure 1, Table 1.

Less than a year after the beginning of the vaccination campaign, several European countries including reported numerous cases of narcolepsy onset following Pandemrix ${ }^{\circledR}$ vaccination $[12,30-34][32,35]$. The elevated incidence came back to the baseline the following year and has stayed low since then [32]. No increase in narcolepsy incidence was reported after administration of the other vaccines authorized in Europe [36, 37]. 
In North America, a suggestive increase in narcolepsy incidence was seen with pH1N1 vaccination in Canada but not in USA [38]. A study conducted in Quebec revealed a minor increase of narcolepsy onset following the immunization campaign using Arepanrix ${ }^{\circledR}$, a similar vaccine to Pandemrix ${ }^{\circledR}$ (both are AS03-adjuvanted) [39]. As the baseline incidence was lower than the well-admitted one, it is possible that cases remain undiagnosed or misdiagnosed. Similarly, a relatively small number of cases included in the study decreased the power to detect a significant association. Nevertheless, these results were surprising since Arepanrix ${ }^{\circledR}$, a close equivalent of Pandemrix ${ }^{\circledR}$ was used to immunize the Canadian population.

Interestingly, simultaneously with the H1N1 vaccination campaign, an increase in narcolepsy incidence was seen together with the occurrence of the H1N1 pandemic. Importantly, clinicians had long suspected that narcolepsy was related to seasonal infections such as influenza [40] and strep throat [41]. Indeed, a study already in 2007 in USA had found an association between self-reported flu a year prior to narcolepsy and in 2009-2010 this was confirmed by an independent study in Chinese [13, 40]. The second study showed that narcolepsy onset is seasonal and preferentially occurs after the flu season [13, 40]. In 2009-2010 flu season it became clear that one of the strongest environmental triggers for narcolepsy was influenza-A as both infection and vaccination for H1N1 pandemic influenzaA [13].

Since narcolepsy onset has been strongly associated only with Pandemrix ${ }^{\circledR}$, several research groups have tried to highlight differential composition and interactions with the human immune system. Vaccines have slightly different purification processes and different manufacturing sites that could potentially modify their qualitative composition and lead to a different activation of the immune system. Most notably, Jacob et al. analyzed both vaccines composition and found that the residue 146 of hemagglutinin displays a 10-fold higher deamidation in Arepanrix (aspartic acid) when compared to Pandemrix ${ }^{\circledR}$ (asparagine). The wild type virus of $2009 \mathrm{pH} 1 \mathrm{~N} 1$, as Pandemrix ${ }^{\circledR}$, also displays an asparagine in position 146, whereas in Arepanrix it needs to be deaminated from aspartic acid into asparagine. This difference in the protein sequence may explain why vaccination with Pandemrix ${ }^{\circledR}$ had higher risk for narcolepsy compared to Arepanrix [42]. Further characterization of avidity parameters with hemagglutinin inhibition assay in Pandemrix vs. Arepanrix vaccinated sera did not show a difference between the two vaccines [43].

\section{Role of humoral immune responses in narcolepsy}

In general, autoimmune diseases are characterized by specific auto-antibodies [44, 45]. However, the search for characteristic narcolepsy autoantibodies has been futile with no auto-antibodies consistently found [46-60]. Such findings may be explained by epitope spreading or by cross-reactivity with specific triggers (Figure 2).

In 2010, three independent research groups found antibody titers directed toward the protein called TRIB2 were significantly higher in a small subset of narcoleptic patients close to cataplexy onset, when compared to controls $[47,53,54]$. These observations were however not replicated in subsequent studies conducted after the 2009 pandemic [56, 61]. One 
hypothesis that could explain this phenomenon might be the presence of a co-infection together with the narcolepsy trigger that occurred during the study periods of these first studies (i.e. 1990s-2000s).

Other research groups focused on the differences of antibody responses in narcoleptic patients after Pandemrix ${ }^{\circledR}$ vaccination in comparison to individuals that didn't develop narcolepsy. Several studies were performed using sera or CSF from narcoleptic Pandemrix ${ }^{\circledR}$ vaccinated individuals. Whereas some highlighted some differences between narcoleptics and controls, others did not [48, 55, 57, 58].

Vaarala et al observed, that Pandemrix ${ }^{\circledR}$ contained higher amounts of structurally altered virus nucleoprotein (NP) when compared to Arepanrix [62]. Analysis of antibody responses revealed that narcoleptic patients had higher antibody titers against detergent-treated NP (structurally altered) versus controls, when compared to non-treated NP antibodies titers that were not significantly different between patients and $H L A-D Q B 1 * 06: 02$ controls. These data suggest that detergent treated NP was differentially recognized by antibodies from narcoleptic versus healthy individuals, a finding that might be a first step in understanding differential immunological responses to these vaccines.

A second study took advantage of the homology between the protein sequence of NP and HCRT2R that has been discovered in a study of HLA-DQB1*06:02 binding (WO2014180999 A1) [55]. IgG binding to HCRT2R, a likely cross-reactivity to the NP epitope, was significantly higher in narcoleptic patients vaccinated with Pandemrix ${ }^{\circledR}$ when compared to other groups except controls. However, at the individual level, the crossreactivity of IgG to HCRT2R and NP was observed only in some of subjects, independently of their pathologic/vaccination/infection status. In contrast to these findings, a study using radio ligand based assay, showed that anti-HCRT2R IgG are present in 3\% of the controls and $5 \%$ of the narcoleptics. The authors explained that the divergence observed between the studies might be first related to the HCRT2R conformation, which can be different depending on the method used, then to the delay between the disease onset and the plasma sampling, which is much longer in Tanaka et al. study [49]. Further, Giannoccaro et al. failed to establish conclusively the presence of anti-HCRTR2 antibodies in narcolepsy cases [63] and we have found anti-HCRTR2 antibodies in 4 narcolepsy cases out of 80 narcolepsy patients using three different quantification methods (unpublished). Interestingly, it appears that Pandemrix ${ }^{\circledR}$ vaccine induced a qualitatively different humoral response in vaccinated individuals as compared to individuals after a natural pandemic influenza infection [64] suggestive of differential immune response to the vaccine and a natural infection.

Antibodies responses to other antigens, such as hypocretin, NP and NS1 (flu proteins) [51], ganglioside GM3 (known to be associated with neurological disorder, such as GuillainBarré), NRXN1 (neurexin-1-alpha), NMDAR, CASPR2 (known to be associated with encephalopathies, including disordered sleep) were assessed in sera or CSF. Antibodies directed against hypocretin [46], NMDAR and CASPR2 [48] were undetectable and antiNS1antibody levels were similar in narcoleptics and controls. Anti-GM3, anti-NP [50] and anti-NRXN1 [65] were higher in narcoleptics, however, they were also detectable in nonnarcoleptic individuals, making them unlikely candidates in the pathogenesis of narcolepsy. 
Other studies looked for sera or CSF biomarkers specific for narcolepsy focusing on cytokines and chemokines [52, 66]. Although these studies suggest immunological changes, their significance remains unclear.

\section{Cellular Immune responses in Narcolepsy}

Among the numerous diseases associated with HLA, narcolepsy is currently the disease with the highest known HLA association with a single particular subtype, HLA-DQB1*06:02. HLA-DQB 1*06:02 along with HLA-DQA1*01:02 forms an MHC class II DQ molecule (DQ0602) that, as other HLA class II molecules, binds self or foreign antigenic peptide to form an antigen presentation complex. This molecular complex then interacts with the $\mathrm{T}$ Cell Receptor (TCR) of CD4+ T-cells to induce activation, a process that leads to the release of soluble factors such as cytokines and chemokines. These orchestrate activation and modulation of other players in immune system, such as cytotoxic CD8+T-cells and antibody-producing cells (B-cells) (Figure 2).

The most likely culprit immune mediator of narcolepsy is likely CD4+ T cell activation, since the strongest genetic risk factors for narcolepsy are HLA-DQB1*06:02 and polymorphisms in the $\mathrm{T}$ cell receptor loci [67]. These are required in the development of CD4+ T helper cell responses. It is now well known that some subsets of CD4+ T cells are involved in the development of autoimmune disease such as type 1-diabetes, multiple sclerosis and rheumatoid arthritis [68-70]. However, there is still limited literature available on the role of cellular immunity in the precipitation of narcolepsy except for strong genetic evidence.

Involvement of $\mathrm{CD}^{+} \mathrm{T}$ cells help to $\mathrm{CD} 8^{+} \mathrm{T}$ cells in hypocretin cell loss is supported by recent work [71]. The authors explored how $\mathrm{CD} 4^{+}$or $\mathrm{CD} 8^{+} \mathrm{T}$ cell targeting hypocretin cells behave in vivo, using mice expressing Orexin-HA neurons. They showed that Orexin-HA specific-CD8+ cells, induced neurons death, even more in presence of Orexin-HA specific$\mathrm{CD} 4^{+} \mathrm{T}$ cells but that Orexin-HA specific-CD4 ${ }^{+} \mathrm{T}$ cells alone migrate in the proximity of hypocretin cells but do not cause cell damage. Other immune trials, such as administration of Pandemrix ${ }^{\circledR}$ or vaccination with hypocretin in many mice models, including DQ0602 humanized mice models, have been unsuccessful (unpublished data).

A recent study used high-dimensional mass cytometry to profile global immune profiles of peripheral blood mononuclear cells in narcolepsy cases and controls. the study revealed that T-cells from narcolepsy cases displayed a differential activation profile and tended to have increased production of pro-inflammatory cytokines [72]. It was not established whether these changes were more likely associated with orexin/hcrt deficiency rather than an active immune process.

Our main working hypothesis currently proposed to explain the association between H1N1 infection / vaccination and narcolepsy onset is based on molecular mimicry. When an individual with a genetic risk for narcolepsy is exposed to specific H1N1 flu epitopes derived from either natural influenza infections or Pandemrix ${ }^{\circledR}$ vaccination, specific CD4+ T cells recognizing DQ0602-flu peptide are activated. These primed flu specific CD4+ T cells 
may then migrate into CNS. In the CNS, these flu specific CD4+ T cells may interact with microglial or dendritic cells in a DQ0602 restricted manner. Flu homologous peptide fragments could be cross-presented to flu-specific CD4+ T cells via DQ0602. A similar effect could occur via HLA class I presentation of hypocretin cell peptide to specific CD8+ $\mathrm{T}$ cells resulting, with the help of the locally activated CD4+ T cells, in CD8+ T cell maturation into cytotoxic cells that can induce neuronal cell death.

\section{Genetic variants at the HLA region predispose to narcolepsy HLA region predispose to narcolepsy}

As mentioned above, narcolepsy is strongly associated with one particular HLA-DQB1 allele, $D Q B 1 * 06: 02$ [8]. Other HLA molecules also modulate risk. Most notably, HLA$D Q B 1 * 03: 01$ increases risk and individuals with this allele have nearly 2 years earlier onset of narcolepsy than those without [9]. Additionally, $H L A-D Q A 1$ gene alleles affect the risk for narcolepsy so that a second copy of $D Q A 1 * 01: 02$ adds predisposition, whereas other $D Q A 1 * 01$ alleles are protective [8]. The effect of these alleles is explained by their binding properties with $D Q B 1 * 06: 02$ as together they can form a functional HLA molecule.

In addition to $H L A-D Q, H L A-D P$ also modulates narcolepsy risk. HLA-DPB $1 * 05: 01$ in particular has been shown to be predisposing $[21,73]$ whereas HLA-DPB $1 * 04: 02$ is protective [21,73]. Similarly, to DQ heterodimers, it is possible that these other heterodimers bind peptides that are either mediating response to environmental triggers such as influenza A infection. Alternatively, they may also affect the development of the TCR repertoire or directly affect how specific narcolepsy risk epitopes are presented.

The majority of HLA associations seen in narcolepsy are mainly found within HLA class II loci, molecules that are recognized by CD4+ $\mathrm{T}$ cells. Interestingly, two recent studies found additional minor associations with $H L A-B * 35$ or $H L A-B * 51: 01$ [21, 73, 74]. These findings suggest that cytotoxic responses mediated through by natural killer or CD8+ T cells are important in the development of narcolepsy.

\section{Genetic variants in narcolepsy}

In narcolepsy (GWAS) genetic associations with narcolepsy support an autoimmune basis. TCR alpha and beta loci are strongly associated with narcolepsy $[9,11,67,75]$. Furthermore, variants in Cathepsin $\mathrm{H}(C T S H)$, an enzyme that process peptides for presentation by HLA on dendritic cells, and TNFSF4 a molecule regulating immune cell fate, are associated with narcolepsy [9]. Finally, variants located within the interferon receptor region (IL1ORB-IFNAR1), the purinergic receptor (P2RY11), the ZNF365 transcription factor as well as chemokine receptor $C C R 1-C C R 3$ regions are associated with narcolepsy $[9,75,76]$. As all these genetic loci have been associated with immune function or other autoimmune disorders, pathway analysis clearly demonstrate narcolepsy is likely autoimmune. 


\section{Conclusion}

The autoimmune basis in narcolepsy is supported by both the role of specific environmental factors, most notably H1N1 infection or Pandemrix ${ }^{\circledR}$ vaccination and by genetic associations with variants located in genes involved in the immune system. Surprisingly however the specific immune mechanisms by which narcolepsy is triggered remain elusive warranting further investigations to understand the how genetic and environmental triggers interact to predispose to narcolepsy.

\section{Acknowledgments}

Financial support and sponsorship

This work has been supported by the Academy of Finland, Finnish Cultural Foundation, Sigrid Juselius Foundation, Orion Research Foundation and Jalmari and Rauha Ahokas Foundation (for HMO).

\section{References}

1. Nishino S, et al. Hypocretin (orexin) deficiency in human narcolepsy. Lancet. 2000; 355(9197):3940. [PubMed: 10615891]

2. Gautvik KM, et al. Overview of the most prevalent hypothalamus-specific mRNAs, as identified by directional tag PCR subtraction. Proc Natl Acad Sci U S A. 1996; 93(16):8733-8. [PubMed: 8710940]

3. de Lecea L, et al. The hypocretins: hypothalamus-specific peptides with neuroexcitatory activity. Proc Natl Acad Sci U S A. 1998; 95(1):322-7. [PubMed: 9419374]

4. Thannickal TC, et al. Reduced number of hypocretin neurons in human narcolepsy. Neuron. 2000; 27(3):469-74. [PubMed: 11055430]

5. Thannickal TC, Nienhuis R, Siegel JM. Localized loss of hypocretin (orexin) cells in narcolepsy without cataplexy. Sleep. 2009; 32(8):993-8. [PubMed: 19725250]

6. Peyron C, et al. A mutation in a case of early onset narcolepsy and a generalized absence of hypocretin peptides in human narcoleptic brains. Nat Med. 2000; 6(9):991-7. [PubMed: 10973318]

7. Juji T, et al. HLA antigens in Japanese patients with narcolepsy. All the patients were DR2 positive. Tissue Antigens. 1984; 24(5):316-9. [PubMed: 6597978]

8. Mignot E, et al. Complex HLA-DR and -DQ interactions confer risk of narcolepsy-cataplexy in three ethnic groups. Am J Hum Genet. 2001; 68(3):686-99. [PubMed: 11179016]

9. Han F, et al. Genome wide analysis of narcolepsy in China implicates novel immune loci and reveals changes in association prior to versus after the 2009 H1N1 influenza pandemic. PLoS Genet. 2013; 9(10):e1003880. [PubMed: 24204295]

10. Hor H, et al. Genome-wide association study identifies new HLA class II haplotypes strongly protective against narcolepsy. Nat Genet. 2010; 42(9):786-9. [PubMed: 20711174]

11. Faraco J, et al. ImmunoChip study implicates antigen presentation to T cells in narcolepsy. PLoS Genet. 2013; 9(2):e1003270. [PubMed: 23459209]

12. Nohynek H, et al. ASO3 adjuvanted AH1N1 vaccine associated with an abrupt increase in the incidence of childhood narcolepsy in Finland. PLoS One. 2012; 7(3):e33536. [PubMed: 22470453]

13. Han F, et al. Narcolepsy onset is seasonal and increased following the $2009 \mathrm{H} 1 \mathrm{~N} 1$ pandemic in China. Ann Neurol. 2011; 70(3):410-7. [PubMed: 21866560]

14. Silber MH, et al. The epidemiology of narcolepsy in Olmsted County, Minnesota: a populationbased study. Sleep. 2002; 25(2):197-202. [PubMed: 11902429]

15. Heier MS, et al. Prevalence of narcolepsy with cataplexy in Norway. Acta Neurol Scand. 2009; 120(4):276-80. [PubMed: 19456307]

16. Hublin C, et al. Epidemiology of narcolepsy. Sleep. 1994; 17(8 Suppl):S7-12. [PubMed: 7701204]

Curr Opin Pulm Med. Author manuscript; available in PMC 2018 November 01. 
17. Hublin C, et al. The prevalence of narcolepsy: an epidemiological study of the Finnish Twin Cohort. Ann Neurol. 1994; 35(6):709-16. [PubMed: 8210228]

18. Ohayon MM, et al. Prevalence of narcolepsy symptomatology and diagnosis in the European general population. Neurology. 2002; 58(12):1826-33. [PubMed: 12084885]

19. Wing YK, et al. The prevalence of narcolepsy among Chinese in Hong Kong. Ann Neurol. 2002; 51(5):578-84. [PubMed: 12112103]

20. Shin YK, et al. Prevalence of narcolepsy-cataplexy in Korean adolescents. Acta Neurol Scand. 2008; 117(4):273-8. [PubMed: 17922892]

21. Miyagawa T, et al. New susceptibility variants to narcolepsy identified in HLA class II region. Hum Mol Genet. 2015; 24(3):891-8. [PubMed: 25256355]

22. Wilner A, et al. Narcolepsy-cataplexy in Israeli Jews is associated exclusively with the HLA DR2 haplotype. A study at the serological and genomic level. Hum Immunol. 1988; 21(1):15-22. [PubMed: 2896649]

23. al Rajeh S, et al. A community survey of neurological disorders in Saudi Arabia: the Thugbah study. Neuroepidemiology. 1993; 12(3):164-78. [PubMed: 8272177]

24. Tafti M, et al. DQB1 locus alone explains most of the risk and protection in narcolepsy with cataplexy in Europe. Sleep. 2014; 37(1):19-25. [PubMed: 24381371]

25. Gragert L, et al. Six-locus high resolution HLA haplotype frequencies derived from mixedresolution DNA typing for the entire US donor registry. Hum Immunol. 2013; 74(10):1313-20. [PubMed: 23806270]

26. Maiers M, Gragert L, Klitz W. High-resolution HLA alleles and haplotypes in the United States population. Hum Immunol. 2007; 68(9):779-88. [PubMed: 17869653]

27. Mignot E, et al. HLA DQB $1 * 0602$ is associated with cataplexy in 509 narcoleptic patients. Sleep. 1997; 20(11):1012-20. [PubMed: 9456467]

28. Juji T, et al. Narcolepsy and HLA in the Japanese. Ann N Y Acad Sci. 1988; 540:106-14. [PubMed: 2905117]

29. Smith GJ, et al. Origins and evolutionary genomics of the 2009 swine-origin H1N1 influenza A epidemic. Nature. 2009; 459(7250):1122-5. [PubMed: 19516283]

30. O'Flanagan D, et al. Investigation of an association between onset of narcolepsy and vaccination with pandemic influenza vaccine, Ireland April 2009-December 2010. Euro Surveill. 2014; 19(17):15-25. [PubMed: 24821121]

31. Dauvilliers Y, et al. Increased risk of narcolepsy in children and adults after pandemic H1N1 vaccination in France. Brain. 2013; 136(Pt 8):2486-96. [PubMed: 23884811]

32. Heier MS, et al. Incidence of narcolepsy in Norwegian children and adolescents after vaccination against H1N1 influenza A. Sleep Med. 2013; 14(9):867-71. [PubMed: 23773727]

33. Miller E, et al. Risk of narcolepsy in children and young people receiving AS03 adjuvanted pandemic A/H1N1 2009 influenza vaccine: retrospective analysis. BMJ. 2013; 346:f794. [PubMed: 23444425]

34. Bardage $\mathrm{C}$, et al. Neurological and autoimmune disorders after vaccination against pandemic influenza A (H1N1) with a monovalent adjuvanted vaccine: population based cohort study in Stockholm, Sweden. BMJ. 2011; 343:d5956. [PubMed: 21994316]

35. Wijnans L, et al. The incidence of narcolepsy in Europe: before, during, and after the influenza A(H1N1)pdm09 pandemic and vaccination campaigns. Vaccine. 2013; 31(8):1246-54. [PubMed: 23246544]

36. Tsai TF, et al. Explorations of clinical trials and pharmacovigilance databases of MF59(R)adjuvanted influenza vaccines for associated cases of narcolepsy. Scand J Infect Dis. 2011; 43(9): 702-6. [PubMed: 21534891]

37. Kim WJ, et al. Incidence of narcolepsy before and after MF59-adjuvanted influenza A(H1N1)pdm09 vaccination in South Korean soldiers. Vaccine. 2015

38. Duffy J, et al. Narcolepsy and influenza A(H1N1) pandemic 2009 vaccination in the United States. Neurology. 2014; 83(20):1823-30. [PubMed: 25320099] 
39. Montplaisir J, et al. Risk of narcolepsy associated with inactivated adjuvanted (AS03) A/H1N1 (2009) pandemic influenza vaccine in Quebec. PLoS One. 2014; 9(9):e108489. [PubMed: 25264897]

40. Picchioni D, Hope CR, Harsh JR. A case-control study of the environmental risk factors for narcolepsy. Neuroepidemiology. 2007; 29(3-4):185-92. [PubMed: 18043003]

41. Aran A, et al. Clinical and therapeutic aspects of childhood narcolepsy-cataplexy: a retrospective study of 51 children. Sleep. 2010; 33(11):1457-64. [PubMed: 21102987]

42**. Jacob L, et al. Comparison of Pandemrix and Arepanrix, two pH1N1 AS03-adjuvanted vaccines differentially associated with narcolepsy development. Brain Behav Immun. 2015; 47:44-57. This study did a detailed mass spectrometric characterization of influenza vaccines used in 2009 pandemic influenza season. [PubMed: 25452148]

43. Canelle Q, et al. Evaluation of potential immunogenicity differences between Pandemrix and Arepanrix. Hum Vaccin Immunother. 2016; 12(9):2289-98. [PubMed: 27105343]

44. Simmons KM, Michels AW. Type 1 diabetes: A predictable disease. World J Diabetes. 2015; 6(3): 380-90. [PubMed: 25897349]

45. du Pre MF, Sollid LM. T-cell and B-cell immunity in celiac disease. Best Pract Res Clin Gastroenterol. 2015; 29(3):413-23. [PubMed: 26060106]

46. van der Heide A, et al. Immunohistochemical screening for antibodies in recent onset type 1 narcolepsy and after H1N1 vaccination. J Neuroimmunol. 2015; 283:58-62. [PubMed: 26004157]

47. Toyoda H, et al. Anti-Tribbles homolog 2 autoantibodies in Japanese patients with narcolepsy. Sleep. 2010; 33(7):875-8. [PubMed: 20614847]

48. Thebault S, et al. Neuronal Antibodies in Children with or without Narcolepsy following H1N1AS03 Vaccination. PLoS One. 2015; 10(6):e0129555. [PubMed: 26090827]

49. Tanaka S, et al. Detection of autoantibodies against hypocretin, hcrtrl, and hcrtr2 in narcolepsy: anti-Hcrt system antibody in narcolepsy. Sleep. 2006; 29(5):633-8. [PubMed: 16774153]

50. Saariaho AH, et al. Autoantibodies against ganglioside GM3 are associated with narcolepsycataplexy developing after Pandemrix vaccination against 2009 pandemic H1N1 type influenza virus. J Autoimmun. 2015

51. Melen K, et al. No serological evidence of influenza A H1N1pdm09 virus infection as a contributing factor in childhood narcolepsy after Pandemrix vaccination campaign in Finland. PLoS One. 2013; 8(8):e68402. [PubMed: 23950869]

52. Kornum BR, et al. Cerebrospinal fluid cytokine levels in type 1 narcolepsy patients very close to onset. Brain Behav Immun. 2015

53. Kawashima M, et al. Anti-Tribbles homolog 2 (TRIB2) autoantibodies in narcolepsy are associated with recent onset of cataplexy. Sleep. 2010; 33(7):869-74. [PubMed: 20614846]

54. Cvetkovic-Lopes V, et al. Elevated Tribbles homolog 2-specific antibody levels in narcolepsy patients. J Clin Invest. 2010; 120(3):713-9. [PubMed: 20160349]

55. Ahmed SS, et al. Antibodies to influenza nucleoprotein cross-react with human hypocretin receptor 2. Sci Transl Med. 2015; 7(294):294ra105.

56. Lind A, et al. A/H1N1 antibodies and TRIB2 autoantibodies in narcolepsy patients diagnosed in conjunction with the Pandemrix vaccination campaign in Sweden 2009-2010. J Autoimmun. 2014; 50:99-106. [PubMed: 24485154]

57. Haggmark-Manberg A, et al. Autoantibody targets in vaccine-associated narcolepsy. Autoimmunity. 2016; 49(6):421-433. [PubMed: 27206786]

58. Saariaho AH, et al. Autoantibodies against ganglioside GM3 are associated with narcolepsycataplexy developing after Pandemrix vaccination against 2009 pandemic H1N1 type influenza virus. J Autoimmun. 2015; 63:68-75. [PubMed: 26227560]

59. Bergman $P$, et al. Narcolepsy patients have antibodies that stain distinct cell populations in rat brain and influence sleep patterns. Proc Natl Acad Sci U S A. 2014; 111(35):E3735-44. [PubMed: 25136085]

60. Katzav A, et al. Passive transfer of narcolepsy: anti-TRIB2 autoantibody positive patient IgG causes hypothalamic orexin neuron loss and sleep attacks in mice. J Autoimmun. 2013; 45:24-30. [PubMed: 23834844] 
61. Dauvilliers Y, et al. Post-H1N1 narcolepsy-cataplexy. Sleep. 2010; 33(11):1428-30. [PubMed: 21102981]

62. Vaarala O, et al. Antigenic differences between AS03 adjuvanted influenza A (H1N1) pandemic vaccines: implications for pandemrix-associated narcolepsy risk. PLoS One. 2014; 9(12):e114361. [PubMed: 25501681]

63. Giannoccaro MP, et al. Antibodies against hypocretin receptor 2 are rare in narcolepsy. Sleep. 2016

64*. Ambati A, et al. H1N1 viral proteome peptide microarray predicts individuals at risk for H1N1 infection and segregates infection versus Pandemrix ((R)) vaccination. Immunology. 2015; 145(3):357-66. first study to report an increased streptococcus specific T-cells in narcolepsy cases. [PubMed: 25639813]

65. Zandian A, et al. Whole-Proteome Peptide Microarrays for Profiling Autoantibody Repertoires within Multiple Sclerosis and Narcolepsy. Journal of Proteome Research. 2017; 16(3):1300-1314. [PubMed: 28121444]

66. Lecendreux M, et al. Impact of cytokine in type 1 narcolepsy: Role of pandemic H1N1 vaccination ? J Autoimmun. 2015; 60:20-31. [PubMed: 25892508]

67. Hallmayer J, et al. Narcolepsy is strongly associated with the T-cell receptor alpha locus. Nat Genet. 2009; 41(6):708-11. [PubMed: 19412176]

68. Roep BO, Kallan AA, De Vries RR. Beta-cell antigen-specific lysis of macrophages by CD4 T-cell clones from newly diagnosed IDDM patient. A putative mechanism of T-cell-mediated autoimmune islet cell destruction. Diabetes. 1992; 41(11):1380-4. [PubMed: 1397714]

69. Pelfrey CM, et al. Identification of a novel T cell epitope of human proteolipid protein (residues 40-60) recognized by proliferative and cytolytic CD4+ T cells from multiple sclerosis patients. $\mathbf{J}$ Neuroimmunol. 1993; 46(1-2):33-42. [PubMed: 7689593]

70. Williams WV, et al. Restricted heterogeneity of T cell receptor transcripts in rheumatoid synovium. The Journal of Clinical Investigation. 90(2):326-333.

$71^{* *}$. Bernard-Valnet R, et al. CD8 T cell-mediated killing of orexinergic neurons induces a narcolepsy-like phenotype in mice. Proceedings of the National Academy of Sciences. 2016; 113(39):10956-10961. first report to show increased hypcretin neuron cytotoxicity in a mouse model.

72. Hartmann FJ, et al. High-dimensional single-cell analysis reveals the immune signature of narcolepsy. J Exp Med. 2016; 213(12):2621-2633. [PubMed: 27821550]

73*. Ollila HM, et al. HLA-DPB1 and HLA class I confer risk of and protection from narcolepsy. Am J Hum Genet. 2015; 96(1):136-46. one of the first reports to find HLA class 1 associations in narcolepsy cases. [PubMed: 25574827]

74*. Tafti M, et al. Narcolepsy-Associated HLA Class I Alleles Implicate Cell-Mediated Cytotoxicity. Sleep. 2016; 39(3):581-7. one of the first reports to find HLA class 1 associations in narcolepsy cases. [PubMed: 26518595]

75. Han F, et al. TCRA, P2RY11, and CPT1B/CHKB associations in Chinese narcolepsy. Sleep Med. 2012; 13(3):269-72. [PubMed: 22177342]

76*. Toyoda H, et al. A polymorphism in CCR1/CCR3 is associated with narcolepsy. Brain Behav Immun. 2015; 49:148-55. Finding a novel association with immunogenetic risk factor in narcolepsy. [PubMed: 25986216] 


\section{Key points}

- $\quad$ Both humoral and cellular immune response is seen in narcolepsy.

- $\quad$ Epidemiological findings connect the development of narcolepsy with influenza-A infection, immunization and with streptococcus pyogenes infection.

- $\quad$ Genetic variants have high predisposition and are located in genes controlling immune reactions and autoimmunity. 


\section{Vaccine coverage for 2009 H1N1 pandemic in Europe}

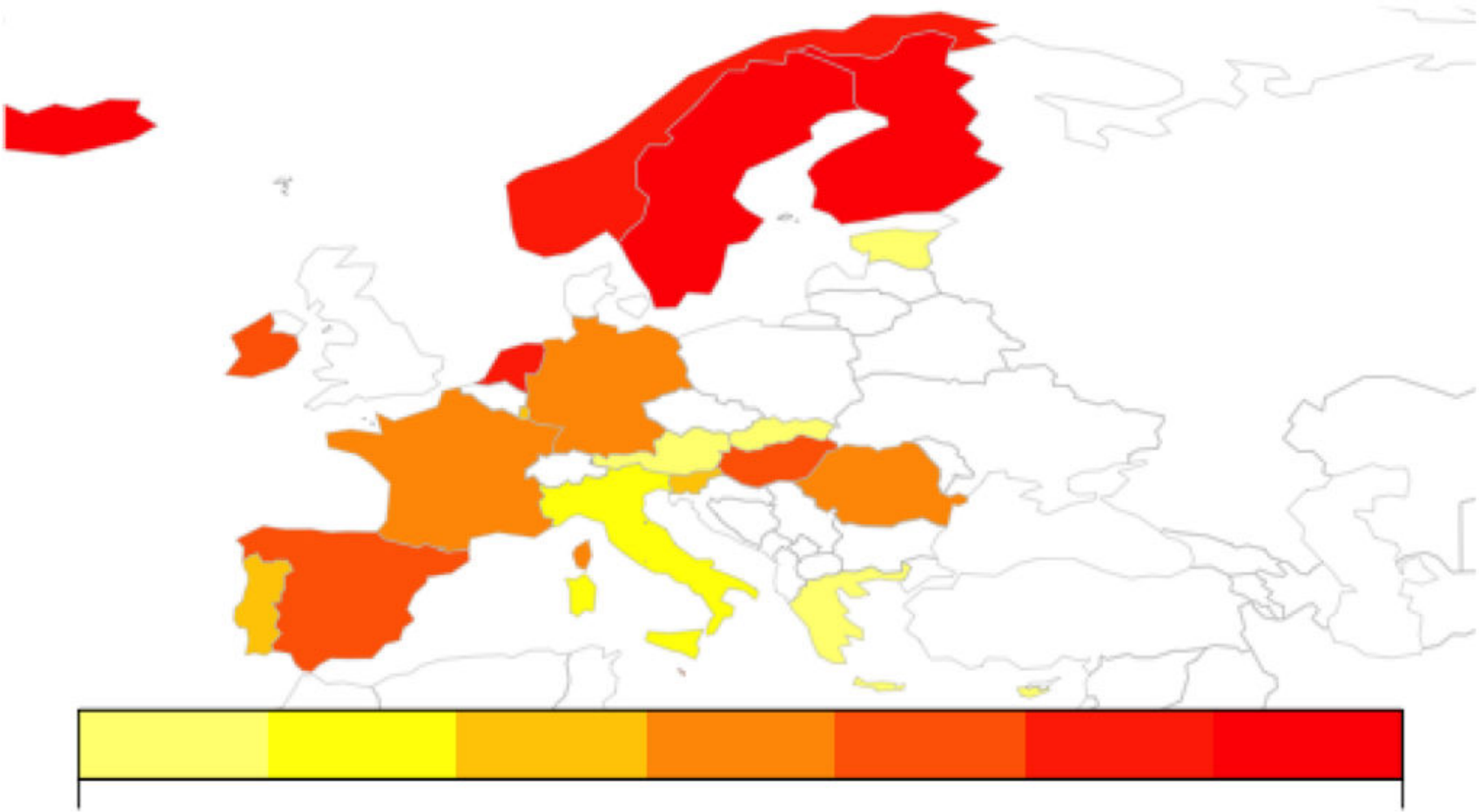

0.4

Percentage of vaccination with H1N1 vaccines

Figure 1.

Vaccination coverage in Europe shows higher percentage of vaccination in Northern Europe. 


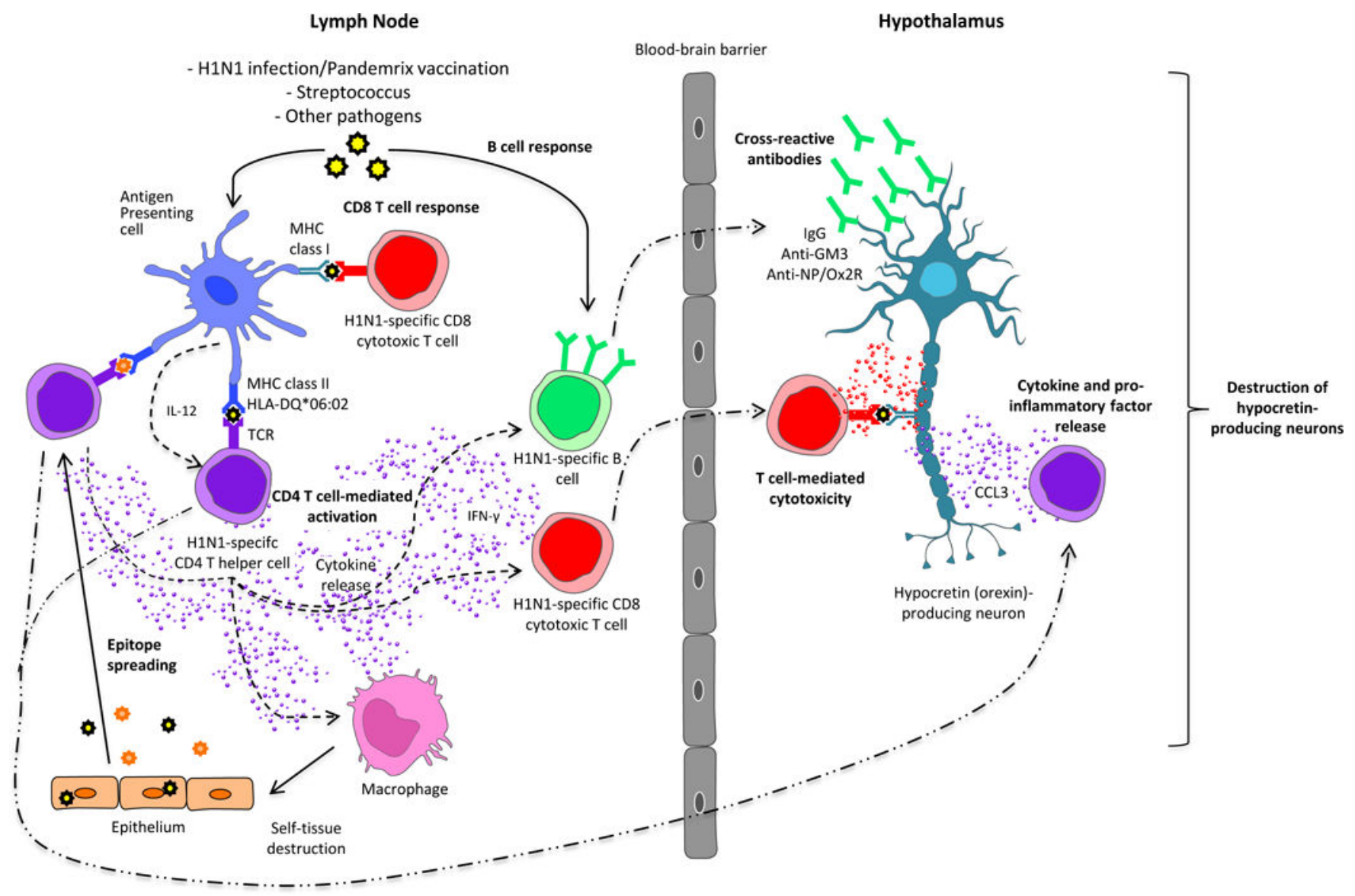

Figure 2.

Possible immune mechanisms inducing narcolepsy via molecular mimicry and/or epitope spreading.

Molecular mimicry. CD4 T cell-mediated activation: after being processed by an antigen presenting cell, $\mathrm{H} 1 \mathrm{~N} 1$ influenza peptides are presented associated to MHC class II molecule (HLA-DQB1*06:02) to CD4+ T cell, that in turn, through cytokine secretion, activate B cells and/or CD8+ T cell that are cross reactive with hypocretin-producing neurons. CD8+ T cell response: after being processed by an antigen presenting cell, H1N1 influenza peptides are presented associated to MHC class I molecule to CD8+ T cell, that in turn will attack hypocretin-producing neurons by cross-reactivity. B cell response: After being activated with H1N1 Influenza, B cells will secrete H1N1-specific antibodies that are cross-reactive with hypocretin-producing neurons. Epitope spreading: after immune response against H1N1 Influenza virus caused tissue damages (macrophages), some self peptides are released and treated by APC as antigens, meaning they are presented to CD4+ T cells that in turn initiate an immune response against self antigens. 
를

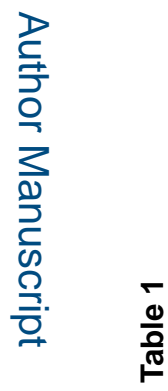

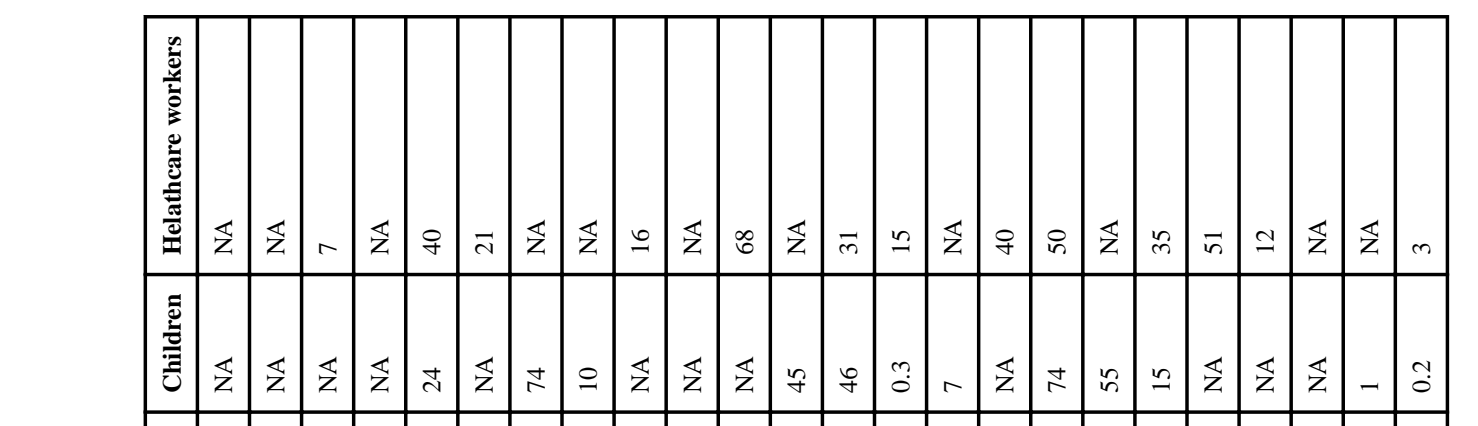

롤

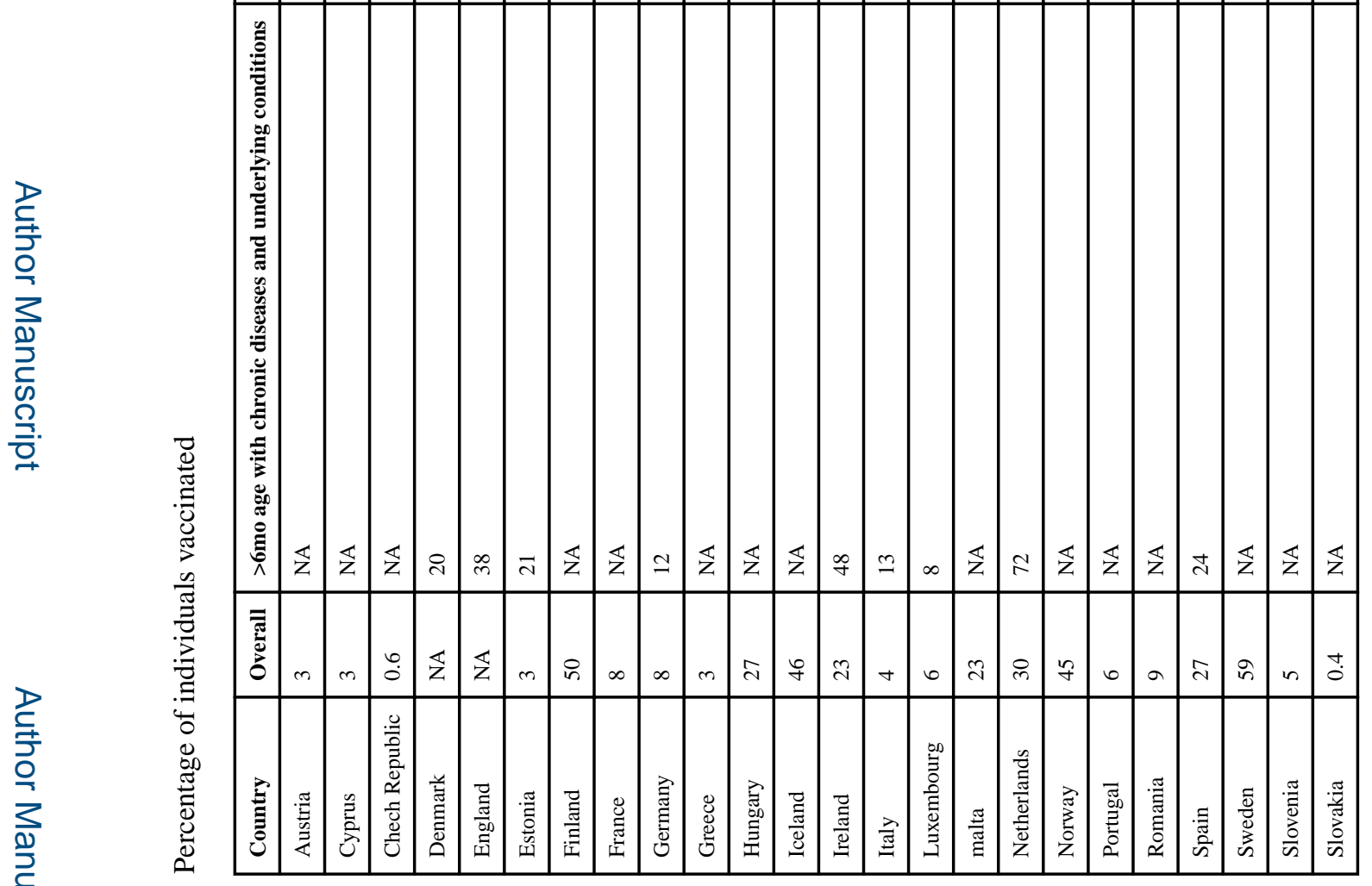

Curr Opin Pulm Med. Author manuscript; available in PMC 2018 November 01. 